\title{
重庆市农业转型发展的时空演进及问题区识别 基于全要素生产率视角
}

\author{
尹朝静 ${ }^{1,2}$, 李兆亮 ${ }^{3}$, 李欠男 ${ }^{4}$,赵同琳 ${ }^{1,2}$
}

(1. 西南大学农村经济与管理研究中心, 重庆 400715；2. 西南大学经济管理学院, 重庆 400715;

3. 武汉工程大学法商学院, 武汉 430205; 4. 华中农业大学经济管理学院, 武汉 430070)

\begin{abstract}
摘要: 研究农业全要素生产率时空演进规律对于合理制定农业转型升级政策具有重要意义。 在使用 DEA-Malmquist 指数模型测算出重庆市 37个县（区）2000-2016年农业全要素生产率 增长的基础上, 结合空间分析方法和核密度估计方法考察农业 TFP 的时空演进特征, 并识别 出问题区域。研究表明：（1）2000-2016年间重庆市农业全要素生产率呈上升趋势, 农业 TFP 指数呈 “U” 型和阶段性波动的变化趋势, 并且表现出明显的空间不平衡性。(2) 农业 TFP 指数增减趋势与技术进步指数的变化趋势基本一致, 技术进步是影响农业全要素生产率的主 要因素。(3) 从全市来看, 农业 TFP 的核密度曲线不断向右移动, 且波峰高度持续上升, 波 峰形态由 “单峰” 分布向 “多峰” 分布转变, 说明重庆市农业全要素生产率的地区差距在考 察期内呈增大趋势。（4）依据 TFP 增长、技术进步和技术效率的关联关系, 识别出三种类型 的问题区域，并针对每类问题区域提出农业转型发展的政策建议。
\end{abstract}

关键词：农业 TFP；时空演进；核密度估计；问题区域

随着中国经济从高速增长进人到高质量发展的 “新常态” 阶段, 从过去的依靠增加 要素投人转向提高全要素生产率促进经济发展, 无疑将是中国成功跨越 “中等收人陷 阱” 的关键。在农业领域中, 全要素生产率一直是学术界研究的 “常青藤” 话题, 近年 来也逐渐得到政府层面的关注。党的十九大报告提出 “提高全要素生产率”。2018年中 央一号文件明确指出 “加快构建现代农业产业体系、生产体系、经营体系, 提高农业创 新力、竞争力和全要素生产率, 加快实现由农业大国向农业强国转变”。故正如一号文件 所言, 农业发展面临环境恶化、资源短缺的约束，依靠资源和物质投人为主的传统生产 方式将不可持续, 要实现农业转型发展必须依靠农业全要素生产率的提高。因此, 研究 典型区域农业全要素生产率增长的时空演进特征, 识别农业转型发展中存在的问题区 域, 对于判断农业经济发展态势, 推动农业转型升级, 实现农业现代化具有重要的现实 意义和理论价值。

已有文献主要围绕农业和农村转型的类型或模式、趋势特征、动力机制及影响因素 等几个方面展开研究。第一, 关于农村和农业转型的类型和模式。王冰 ${ }^{[1]}$ 认为外部环境和 特殊的国情决定了中国农村社会转型模式, 并且农村的工业化和农村剩余劳动力的转移

收稿日期：2018-09-26; 修订日期：2019-01-10

基金项目：教育部人文社会科学研究项目（18XJC790018）；重庆市人文社科重点研究基地项目（18SKB033）; 国家 自然科学基金青年项目（71803145）

作者简介: 尹朝静 (1989- ), 男, 四川内江人, 博士, 讲师, 主要从事农业技术经济学和资源与环境经济学研究。 E-mail: yinchaojing@163.com

通讯作者: 李兆亮（1986- ), 男, 湖北武汉人, 博士, 讲师, 主要从事农业技术经济理论与政策研究。

E-mail: tigerlihuayi@163.com 
会是主导模式。张风[2]则通过山东寿光和浙江义乌的实例对农村经济转型展开分析。还有 不少学者集中探讨区域层面中国农业和农村转型的地域类型和地方模式 ${ }^{[-5]}$ 。第二, 关于 农村和农业转型的趋势特征。刘奇 ${ }^{[}{ }^{\circ}$ 罙讨了农村社会转型过程中社会形态和结构及农民的 社会心理和价值观念的变化特征，提出农村已经从传统的 “农耕社会” 演变成 “农工社 会”，而农民的社会心理呈现出传统与现代、多元与异质、积极与消极互相交织的态势。 赵䀐等[1采用数理统计和空间分析方法对农村经济转型的研究表明, 江苏省农村经济转型 呈现明显的空间地域分异。第三, 关于农村和农业转型的动力机制及影响因素。不少学 者对农村和农业转型过程的动力机制展开比较深人的分析, 例如赵红军 ${ }^{[8]}$ 、龚为纲等 ${ }^{[9]}$ 、 郑有贵 ${ }^{[10]}$ 、张富刚等 ${ }^{[1]}$ 。而翁鸣 ${ }^{[12]}$ 及罗明忠等 ${ }^{[13]}$ 对中国农业转型发展的问题、经验和方向

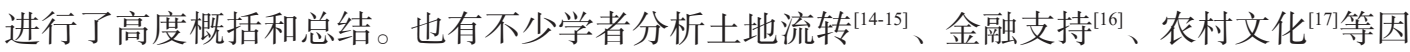
素对农村和农业转型发展的影响。除此之外，有学者尝试采用定量测算的方法对农业和 农村转型进行研究, 例如赵形等 ${ }^{[1]}$ 和沈惊宏等 ${ }^{[18]}$ 。而全要素生产率分析框架也逐渐受到学 者的青睐。

实际上, 全要素生产率已被广泛应用于分析资源节约与农业增长的关系。在国家层 面, Headey 等 ${ }^{[19}$ 利用 $\mathrm{FAO}$ 数据对农业全要素生产率增长率进行了测算。Trindade ${ }^{\text {等 }}{ }^{[20]}$ 对 南美洲 10 个国家的农业全要素生产率增长进行研究, 认为南美洲农业全要素生产率增长 速度并未放缓。另外, 不少国内外学者对中国农业全要素生产率增长进行了研究, 并较 为一致地认为改革开放以来中国农业全要素生产率增长经历了快速增长、停滞、重新快 速增长、再次增长放慢和重新快速增长这一演变历程 ${ }^{[2-24]}$ 。此外, 一些学者采用微观农户 数据对农业全要素生产率进行了研究。李谷成等 ${ }^{[23]}$ 利用农户数据将农业全要素生产率增 长分解为技术效率、技术进步、配置效率和规模效率变化, 并认为资源配置效率是全要 素生产率波动的决定性因素。朱娅等 ${ }^{[26]}$ 采用DEA 测算江苏省农户农业全要素生产率，并 探讨农民的现代性与农业全要素生产率的关系。然而，采用全要素生产率分析框架对农 业和农村转型进行探讨的文献仍旧不多, 只有少数学者从全要素生产率视角对农业转型 发展展开研究。马晓冬等 ${ }^{[2]}$ 利用全要素生产率分析框架对江苏省农业转型发展进行研 究, 提出加快农业转型发展具体的对策建议。而严先锋等 ${ }^{[28]}$ 在科学识别中国农业绿色发 展的基础上，对农业绿色转型干预机制进行了研究。

综上所述, 尽管现有研究对农业和农村转型升级展开了比较全面的探讨, 并取得了 丰硕的研究成果, 但却很少有文献对重庆市农业转型发展进行研究, 而从全要素生产率 视角深人探讨重庆市农业转型发展的研究则更少。2000年以来，重庆市各地区积极推进 农业转型发展。截至2016年，全市拥有 “三品一标” 认证农产品 2740 个，相橘、椎菜等 七大农业特色产业链综合产值达 1040 亿元，创建全国休闲农业与乡村旅游示范区县 10 个，最美休闲乡村和中国美丽田园 23 个，农业机械化、信息化、市场化水平提升明显， 农业现代化进程不断加快。然而，重庆具有 “大城市、大农村、大库区” 的特征，各地 的自然环境、经济基础及区位条件差异很大，使得重庆市农业经济发展区域差异明显， 农业转型发展表现出明显的时空差异特征。鉴于此，本文采用DEA-Malmquist指数模型 和空间分析方法, 系统考察了 2000-2016年重庆市农业全要素生产率的时空变化和动态演 进特征，识别农业转型发展中的问题区域，并提出针对性的政策建议，以期为重庆推进 农业现代化发展政策的制定提供科学依据，同时为山区丘陵地区农业转型发展提供借鉴 和参考。 


\section{1 研究方法与数据来源}

\section{1 研究方法}

Kernel 密度估计主要用于随机变量的概率密度估计，利用连续的密度曲线描述随机 变量的分布形态。假设一组连续型随机变量 $X$ 的密度函数为 $f(x)$, 在点 $x$ 的概率密度的 估计式为:

$$
f(x)=\frac{1}{N h} \sum_{i=1}^{N} K\left(\frac{X_{i}-x}{h}\right)
$$

式中： $N$ 为观测值的个数; $h$ 为带宽; $K(\cdot)$ 为核函数; $X_{i}$ 为独立同分布的观测值; $x$ 为 均值。在核密度方法中核密度函数对带宽十分敏感，因而确定带宽是获取最优拟合结果 的关键，最佳的带宽不宜过大或过小，通过拇指法则（Rule of Thumb，ROT）计算得到 最优带宽。另外, 本文采用高斯核函数对重庆市农业 TFP 的分布动态演进进行估计, 具 体函数表达式如下:

$$
K(x)=\frac{1}{\sqrt{2 \pi}} \exp \left(-\frac{x^{2}}{2}\right)
$$

核密度估计属于非参数估计，没有确定的函数表达式，需要利用图形对比的方式考 察变量分布的位置、形态和延展性等方面的信息。

\section{2 样本数据与农业全要素生产率的测算}

\section{2 .1 样本数据}

对重庆市农业全要素生产率进行测算，需要使用县级层面农业生产投人和产出数 据。考虑到数据一致性和可获取性, 并结合已有研究成果及重庆市农业发展的实际情 况，本文构建出测算农业全要素生产率的投人产出指标 ${ }^{[27,29]}$ 。其中，产出指标包括农林牧 渔业总产值、粮食产量和农村居民人均收人; 投人指标包括农作物播种面积、乡村从业 人员数量、化肥投人、农业机械投人和农药投人。需要说明的是，对于个别投人产出数 据缺失和极少的异常值, 通过相关县（区）或相邻年份数据进行修正，而农林牧渔业总 产值和农村居民人均收人均换算成 2000 年可比价。以 2011 年重庆市区县行政区划为标 准，包括 19 个市辖区、15 个县、4 个自治县，将样本确定为重庆市 37 个区县 ${ }^{1}$ 。本文将 样本数据的考察周期确定为 2000-2016年，最终形成重庆市 37 个县（区）2000-2016年的 面板数据。数据主要来自《重庆统计年鉴》(2001-2017年) 和地方统计年鉴。此外，研 究数据还包括国家基础地理信息库的重庆市 1 : 50000 矢量图层。

\section{2 .2 农业全要素生产率的测算}

本文使用DEA-Malmquist 指数方法测算农业全要素生产率。Fare 等 ${ }^{[30]}$ 在规模不变的 假设下，将全要素生产率分为技术效率变化（TEC）和技术进步变化（TC）。通过将包 含若干个决策单元在内的面板数据为对象, 运用距离函数构造生产最佳前沿面, 并将每 个决策单元实际生产情况与最佳前沿面进行比较, 从而将基于产出导向的 Malmquist指数

(1) 渝中区位于重庆市主城区，经济以第三产业为主，基本没有农业和工业，因而未包括在内。结合重庆市发展 战略和地理区位，将37个县（区）划分为 “一圈两翼”：一小时经济圈，包括大渡口区、江北区、沙坪坝区、九龙 坡区、南岸区、北碚区、渝北区、巴南区、綦江区、潼南县、铜梁县、大足区、荣昌县、璧山县、江津区、合川 区、永川区、南川区、涪陵区、长寿区; 渝东南翼，包括黔江区、武隆县、石柱县、秀山县、西阳县、彭水县; 渝 东北翼，包括万州区、梁平县、城口县、丰都县、垫江县、忠县、开县、云阳县、奉节县、巫山县、巫溪县。 
分解为技术进步与技术效率：

$$
\begin{gathered}
M_{O}\left(x^{t+1}, y^{t+1}, x^{t}, y^{t}\right)=\left[\left(\frac{D_{o}^{t}\left(x^{t+1}, y^{t+1}\right)}{D_{o}^{t}\left(x^{t}, y^{t}\right)}\right) \times\left(\frac{D_{o}^{t+1}\left(x^{t+1}, y^{t+1}\right)}{D_{o}^{t+1}\left(x^{t}, y^{t}\right)}\right)\right]^{1 / 2}= \\
\frac{D_{o}^{t+1}\left(x^{t+1}, y^{t+1}\right)}{D_{o}^{t}\left(x^{t}, y^{t}\right)} \times\left[\left(\frac{D_{o}^{t}\left(x^{t+1}, y^{t+1}\right)}{D_{o}^{t+1}\left(x^{t+1}, y^{t+1}\right)}\right) \times\left(\frac{D_{o}^{t}\left(x^{t}, y^{t}\right)}{D_{o}^{t+1}\left(x^{t}, y^{t}\right)}\right)\right]^{1 / 2}=T E C \times T C
\end{gathered}
$$

式中： $x^{t} 、 y^{t}$ 分别代表 $t$ 时的投人和产出向量； TEC 代表技术效率变化，衡量决策单元 资源配置和利用效率改善程度；TC 代表技术进步变化，表示生产技术的改进程度。

Hall 等 ${ }^{[31]}$ 认为仅仅比较不同经济主体的平均增长率，不能真实客观地反映不同经济

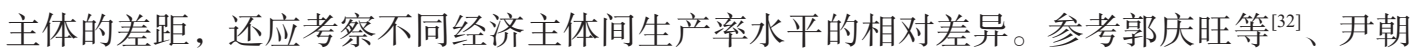
静等 ${ }^{[33]}$ 的研究，本文在测算重庆各县（区）2000-2016年间农业 TFP 的基础上，通过构建 累积农业相对全要素生产率 $(C M L)$ ，作为核密度估计的基础指标。其中，第 $h$ 个 $(h=1,2, \cdots, 37$ ) 县（区）在 $T$ 年的累积农业相对全要素生产率:

$$
C M L_{h}=D_{h}^{2000}\left(x_{h}^{2000}, y_{h}^{2000}\right) \times \prod_{t=2001}^{T} M L_{h}^{t}
$$

式中： $t$ 表示时间; $D_{h}^{2000}\left(x_{h}^{2000}, y_{h}^{2000}\right)$ 表示第 $h$ 个省份在 2000 年的距离函数; $M L_{h}^{t}$ 分别表 示第 $h$ 个 $(h=1,2, \cdots, 37)$ 省份在 $t$ 年的 Malmquist 生产率指数，从而可得到历年的累积 农业相对全要素生产率。

\section{2 结果分析}

\section{1 重庆农业全要素生产率增长的时空特征}

\section{1 .1 重庆市农业全要素生产率指数的时序特征}

本文采用2000-2016年重庆市37个县（区）的面板数据，利用Deap 2.1 软件对重庆 市农业 Malmquist生产率指数进行测算，从而考察重庆市农业全要素生产率增长及其分解 效率指数的变化趋势（图 1)。由图 1 可知：第一，重庆市农业全要素生产率指数呈现出 明显的 “U” 型波动和阶段性特征，主要可以划分为 2000-2007年和 2007-2016 年两个波 动周期。2000-2007年，农业全要素生产率指数从 2001 年的 0.941 快速上升到 1.026, 接着 迅速下降到 2006 年的 0.861 , 最后拉升到 2007 年的 1.149。其中，2003-2006 年农业全要 素生产率出现较大降幅，通过对投人产出指标的变化情况分析发现，在这期间农林牧渔 业总产值、粮食产量以及家庭经营纯收人的增长幅度比较小，2006年甚至出现了负增 长, 可能的原因是我国加人世贸组织后, 农产品贸易受到国际市场的短期冲击, 导致了 农产品价格波动较大。另外，2006年重庆市发生严重的特大干旱灾害，对该年农业生产 造成了重大损失。2007-2016年间，农业全要素生产率指数从 2007 年的 1.149 下降到 2016 年的 1.016 。通过对农林牧渔业总产值的变化情况进行分析，发现 2007 年和 2008 年重庆 市农林牧渔业总产值获得较快增长，2008年之后增长有所减缓。可能的原因是，2007年 重庆市被确认为城乡综合配套改革试验区, 政府为促进农业转型、统筹城乡发展, 逐步 加大对农村基础设施投人力度，促进了这两年农业经济发展。然而，由于快速城市化的 虹吸效应，造成农业科研投人不足、科技创新能力低等问题，加上 2008 年金融危机的影 响, 农业经济增长有所下降, 但随后逐渐平稳增长。第二, 重庆市农业全要素生产率指 


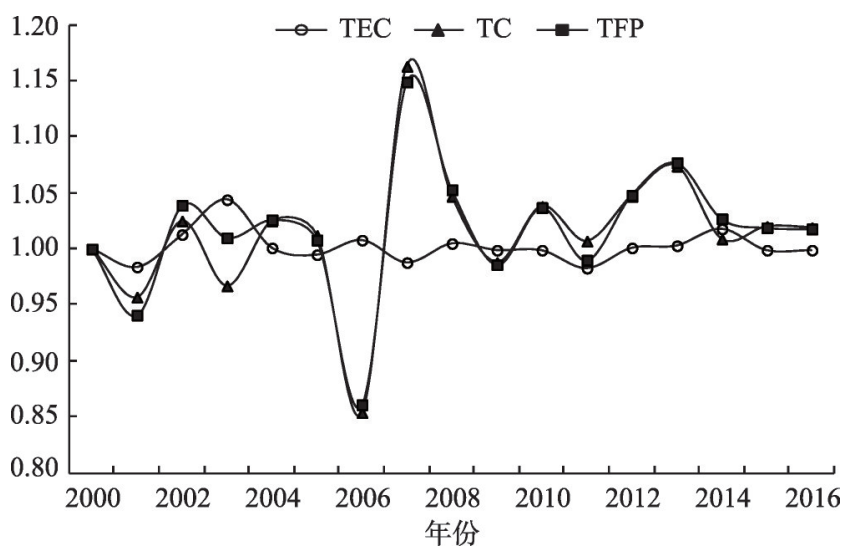

图 1 2001-2016年重庆市农业 Malmquist生产率指数及其分解

Fig. 1 Malmquist efficiency index and its decomposition of agriculture in Chongqing during 2000-2016

数与技术进步指数的增减趋势基本一致, 表明技术进步是影响农业全要素生产率的主要 因素。与技术进步指数相比, 技术效率指数的变化幅度相对更小，但其与农业全要素生 产率指数仍有着很强的相关性，表明技术效率是影响农业全要素生产率的重要因素。

2.1.2 重庆市农业全要素生产率指数的空间特征

由表 1 可知，2000-2016年间，重庆市各县（区）农业全要素生产率呈现出明显的空 间不平衡性，东西差异明显。一小时经济圈的农业全要素生产率最高，渝东南翼地区次 之, 渝东北翼地区最后, 增长率分别为 $3.3 \% 、 0.3 \%$ 和 $-0.6 \%$ 。分地区来看, 一小时经济 圈中农业全要素生产率增长最高的是大渡口区，增长率达到 $13.9 \%$, 最慢的为綦江区, 增长率为 $-0.8 \%$ 。渝东南翼地区中增长最快的为黔江区，增长率为 $2.0 \%$, 最慢的为秀山 县, 为 $-1.2 \%$ 。而渝东北翼地区中增长最快的为巫山县, 增长率为 $0.3 \%$, 最慢的为垫江 县, 为 $-1.6 \%$ 。另外, 一小时经济圈的技术进步增长率为 $3.3 \%$, 而渝东南翼地区和渝东 北翼地区的技术进步增长率均为负，分别为 $-0.3 \%$ 和 $-1.1 \%$ 。与此同时，一小时经济圈的 技术效率增长率为 $-0.1 \%$, 而渝东南翼地区和渝东北翼地区的技术效率增长率均为正, 分别为 $1.9 \%$ 和 $0.6 \%$ 。

为了更直观地反映 2001-2016年重庆市 37 个县（区）农业全要素生产率增长率的总 体变化情况, 选取重庆市各县（区）2001年和2016年农业全要素生产率指数，借助 ArcGIS 10.1 操作平台，揭示重庆市各地区农业全要素生产率指数值的变化趋势（图 2）。 2001 年重庆市农业全要素生产率指数值大于 1 的地区比较少, 主要包括一小时经济圈的 九龙坡区、璧山县和江北区、渝东北翼的巫山县、巫溪县和开县以及渝东南翼的武隆 县、西阳县、铜梁县和黔江县两区 8 县, 说明 2001 年 10 个地区农业全要素生产率较 2000 年有所提高, 呈增长趋势。到 2016 年, 重庆市农业全要素生产率指数大于 1 的地区明显 增多, 达到 32 个县（区)，除南岸区、江北区、黔江区、垫江县和梁平县外，巫溪县、 永川区和城口县等其余 32 个县（区）农业全要素生产率指数均大于 1 , 说明 2016 年大部 分县（区）农业全要素生产率较 2015 年有所上升。

\section{2 重庆农业全要素生产率增长的动态演进}

在构造累积相对农业全要素生产率指数的基础上，利用核密度估计考察2000-2016年 重庆市农业全要素生产率增长分布的动态演进。 
表 $12000-2016$ 年重庆市各县（区）农业生产率增长及其分解

Table 1 The growth of agricultural Malmquist efficiency index and its decomposition in Chongqing duing 2000-2016

\begin{tabular}{|c|c|c|c|c|c|c|c|}
\hline 地区 & $\begin{array}{c}\text { 曼奎斯特 } \\
\text { 生产率指数 }\end{array}$ & $\begin{array}{c}\text { 技术进步 } \\
\text { 指数 }\end{array}$ & $\begin{array}{l}\text { 技术效率 } \\
\text { 变化指数 }\end{array}$ & 地区 & $\begin{array}{l}\text { 曼奎斯特 } \\
\text { 生产率指数 }\end{array}$ & $\begin{array}{c}\text { 技术进步 } \\
\text { 指数 }\end{array}$ & $\begin{array}{l}\text { 技术效率 } \\
\text { 变化指数 }\end{array}$ \\
\hline 一小时经济圈 & 1.033 & 1.033 & 0.999 & 长寿区 & 1.020 & 1.018 & 1.001 \\
\hline 大渡口区 & 1.139 & 1.139 & 1.000 & 渝东南翼 & 1.003 & 0.997 & 1.019 \\
\hline 江北区 & 1.101 & 1.101 & 1.000 & 黔江区 & 1.020 & 1.010 & 1.000 \\
\hline 沙坪坝区 & 1.061 & 1.061 & 1.000 & 武隆县 & 1.001 & 1.005 & 0.990 \\
\hline 九龙坡区 & 1.080 & 1.080 & 1.000 & 石柱县 & 0.989 & 0.990 & 0.999 \\
\hline 南岸区 & 1.061 & 1.062 & 0.998 & 秀山县 & 0.988 & 0.993 & 1.007 \\
\hline 北碚区 & 1.044 & 1.045 & 0.998 & 西阳县 & 1.013 & 0.991 & 1.019 \\
\hline 渝北区 & 1.037 & 1.037 & 1.000 & 彭水县 & 1.006 & 0.992 & 1.013 \\
\hline 巴南区 & 1.005 & 1.005 & 1.000 & 渝东北翼 & 0.994 & 0.989 & 1.006 \\
\hline 綦江区 & 0.992 & 0.999 & 0.994 & 万州区 & 0.990 & 0.988 & 1.002 \\
\hline 潼南县 & 1.017 & 1.021 & 0.996 & 梁平县 & 0.987 & 0.987 & 1.000 \\
\hline 铜梁县 & 1.024 & 1.022 & 1.002 & 城口县 & 0.991 & 0.988 & 1.003 \\
\hline 大足区 & 1.010 & 1.008 & 1.002 & 丰都县 & 0.995 & 0.992 & 1.004 \\
\hline 荣昌县 & 1.019 & 1.017 & 1.002 & 垫江县 & 0.984 & 0.986 & 0.998 \\
\hline 璧山县 & 1.010 & 1.010 & 1.000 & 忠 县 & 0.989 & 0.985 & 1.003 \\
\hline 江津区 & 0.995 & 0.995 & 1.000 & 开 县 & 1.001 & 0.991 & 1.011 \\
\hline 合川区 & 0.998 & 0.998 & 1.000 & 云阳县 & 0.998 & 0.986 & 1.012 \\
\hline 永川区 & 1.009 & 1.011 & 0.999 & 奉节县 & 0.996 & 0.987 & 1.010 \\
\hline 南川区 & 1.001 & 1.005 & 0.997 & 巫山县 & 1.003 & 0.993 & 1.010 \\
\hline 涪陵区 & 1.000 & 1.000 & 0.999 & 巫溪县 & 1.002 & 0.991 & 1.011 \\
\hline
\end{tabular}

注：本表中各指数为分县（区）历年的几何平均数，总平均数亦为各县（区）的几何平均数。

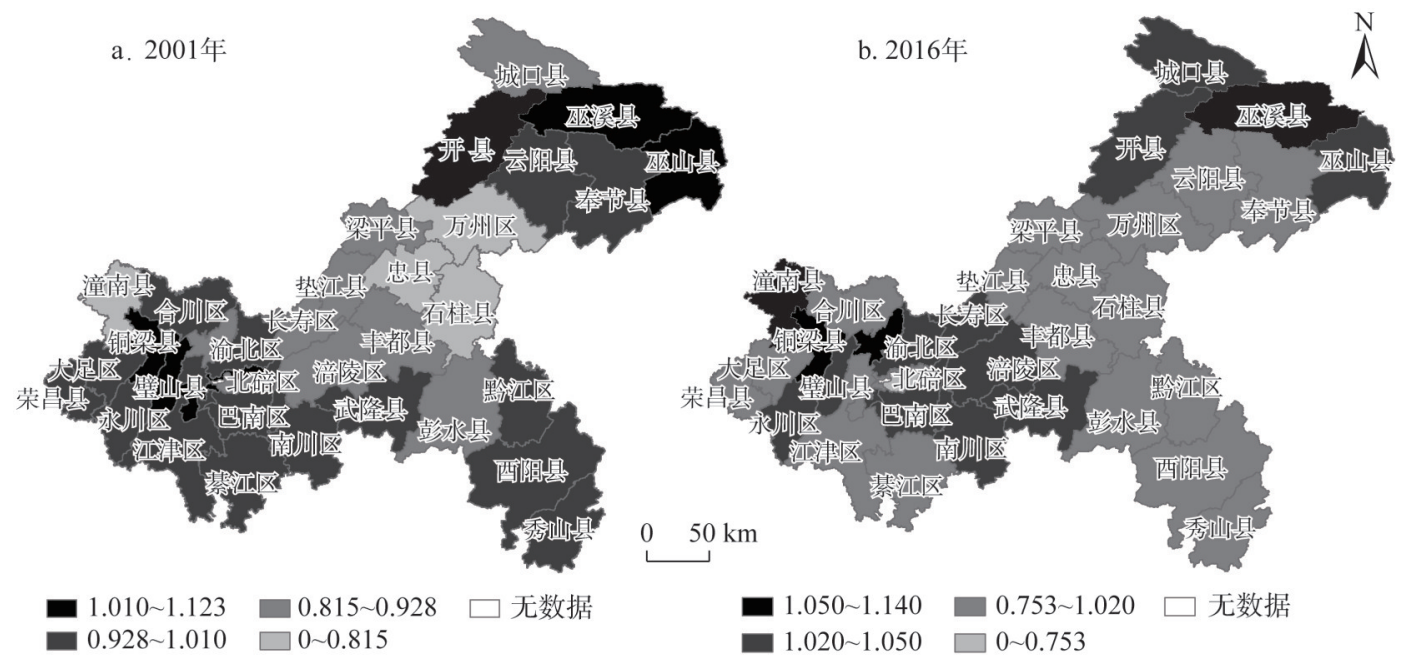

图 22001 年和 2016 年重庆市农业全要素生产率指数空间格局变化

Fig. 2 The spatial distribution of agricultural total factor productivity index of Chongqing in 2001 and 2016 


\subsection{1 重庆 37 个县( 区)农业全要素生产率的核密度估计}

图 3 描述了重庆 37 个县（区）农业全要素生产率在2001-2016年间的动态演进。从整 体上看，密度函数中心向右移动，波峰高度持续下降，变化区间逐渐增长，这表明在考 察期内重庆市大多数县（区）农业全要素生产率存在增长，但地区差距变大; 波峰方 面，由“单峰” 分布逐渐向 “多峰” 分布转变。从演变进程来看，与 2001 年相比，2006 年峰值轻微减小，变化区间小幅减小，说明该阶段重庆农业全要素生产率地区差距有所 减小；2011年与 2006 年相比，峰值减小并出现多峰分布，变化区间增大，说明该阶段农 业全要素生产率地区差距变大的同时出现了多极分化现象；2016年与 2011 年相比，密度 函数中心小幅右移，峰值进一步减小同时呈 “多峰” 分布，变化区间小幅增加，说明该 阶段在考察期内农业全要素生产率地区差距变大。

\subsection{2 一小时经济圈地区农业全要素生产率的核密度估计}

图 4 描述了重庆一小时经济圈地区农业全要素生产率在2001-2016 年间的动态演进。 从整体上看，密度函数中心向右或向左移动趋势不明显，波峰高度持续下降，变化区间 逐渐增长，表明在考察期内农业全要素生产率的地区差距逐渐变大；波峰方面，由“一 大一小” 的 “双峰” 分布逐渐向 “单峰” 分布转变。从演变进程来看，相比 2001 年, 2006年峰值明显下降, 变化幅度大幅增加, 说明该阶段一小时经济圈的农业全要素生产 率地区差距变大；2011年与 2006 年相比，峰值持续减小，变化区间继续增大，说明该阶 段农业全要素生产率地区差距继续变大；2016年与 2011 年相比，峰值持续减小且呈单峰 分布，变化区间进一步增加，说明该阶段农业全要素生产率地区差距进一步加大。

2.2.3 渝东北翼地区农业全要素生产率的核密度估计

图 5 描述了渝东北翼地区农业全要素生产率在2001-2016年间的动态演进。从整体上 看，密度函数中心向右移动，波峰高度持续上升，变化区间小幅减小，表明在考察期内 渝东北翼农业全要素生产率存在增长, 且存在增长的县（区）个数在增加; 波峰方面, 由 “单峰” 分布向 “多峰” 分布转变。从演变进程来看, 相比 2001 年，2006年峰值明显 上升，区间变化幅度减小，说明这阶段农业全要素生产率地区差距在缩小；2011年与

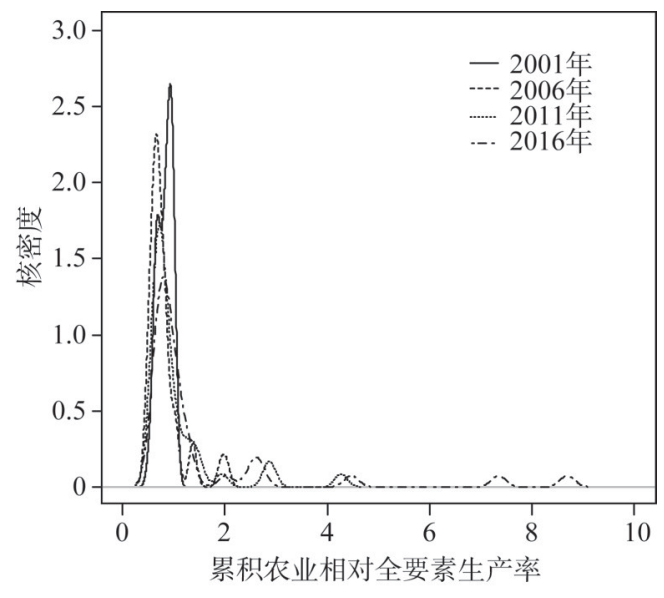

图 3 重庆 37 个县（区）农业全要素生产率演进

Fig. 3 Agricultural total factor productivity evolution of Chongqing

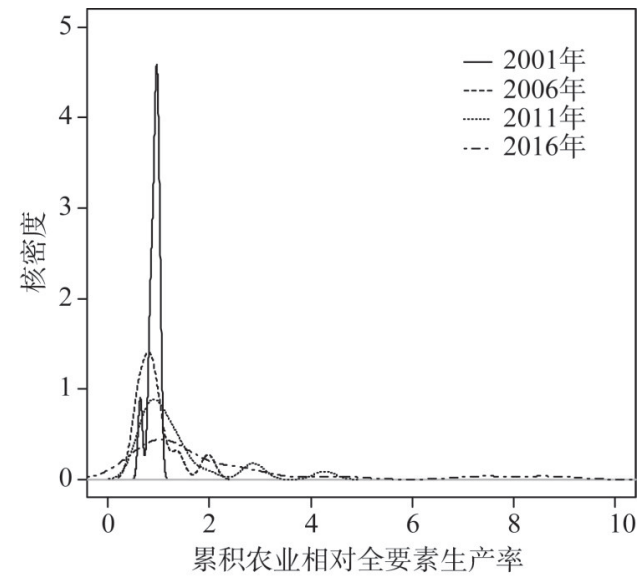

图 4 一小时经济圈农业全要素生产率的演进

Fig. 4 Agricultural total factor productivity evolution of 37 districts in One-hour Economic Circle 
2006年相比，峰值持续上升并呈现 “双峰” 分布迹象，变化区间轻微增大，说明这阶段 农业全要素生产率地区差距增大且出现两极分化现象。2016年与 2011 年相比, 密度函数 中心小幅右移，峰值继续上升同时呈 “三峰” 分布，变化区间增加，表明这阶段农业全 要素生产率地区差距继续加大且呈现多极分化趋势。

\section{2 .4 渝东南翼地区农业全要素生产率的核密度估计}

图6描述了渝东南翼地区农业全要素生产率在2001-2016年间的动态演进。从整体上 看，密度函数中心向右移动，波峰高度逐渐减小，变化区间小幅增加，表明在考察期内 渝东南翼地区多数地区农业全要素生产率存在增长，但增长县（区）数量在减少; 波峰 分布方面，由“多峰”向 “单峰” 转变。从演变进程看，相比 2001 年，2006 年密度中心 向右轻微移动, 峰值轻微减小且 “双峰” 分布趋势减弱, 说明这阶段农业全要素生产率 地区差距减小; 相比 2006年，2011年峰值大幅增加并出现 “多峰” 分布，说明这阶段农 业全要素生产率地区差距增大; 相比 2011 年，2016年密度函数中心大幅右移，峰值下降 同时呈 “单峰” 分布，说明这阶段农业全要素生产率存在增长，且地区差距逐渐减小。

\section{3 农业效率问题区域识别及效率提升对策}

考虑到 Malmquist生产率指数是相对变化量指标，因而将各县（区）的农业全要素生 产率指数、技术进步指数和效率变化指数分别与全市对应的均值比较。具体地，将技术 效率和技术进步指数均低于全市平均水平，全要素生产率指数低于全市均值的县（区） 归纳为技术效率与技术进步滞后型地区。将技术进步指数低于全市均值，技术效率指数 高于全市均值，全要素生产率指数低于全市均值的县（区）归纳为技术进步滞后引发 TFP 增长滞后型地区。将技术效率指数低于全市均值, 技术进步指数高于全市均值, 全 要素生产率指数高于全市均值的县（区）归纳为技术效率滞后型地区。另外，技术效率 指数、技术进步指数和全要素生产率指数均高于全市均值的县（区）为其他区域。由 此，采用GIS 空间查询工具提取效率改进值低于全市平均水平的地区，通过叠加分析识 别出农业效率的问题区域（图 7)。由图 7 可知，问题区域可分为三类：

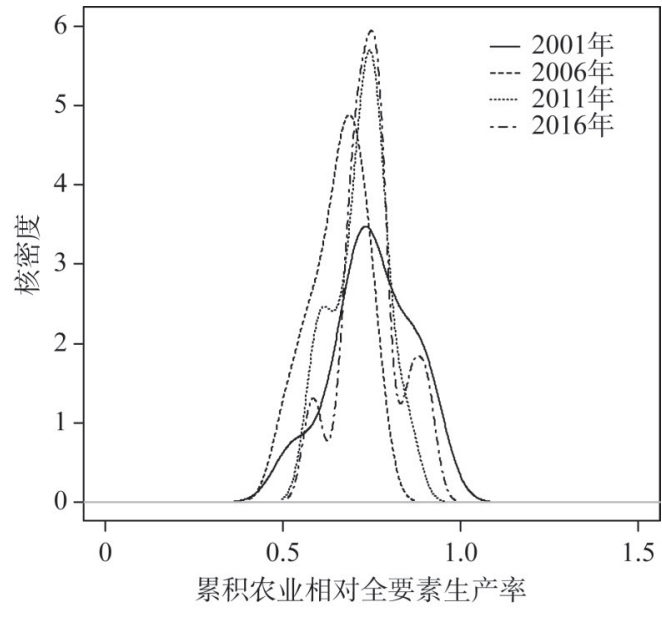

图 5 渝东北翼地区农业全要素生产率演进

Fig. 5 Agricultural total factor productivity evolution of Chongqing's northeast wing area

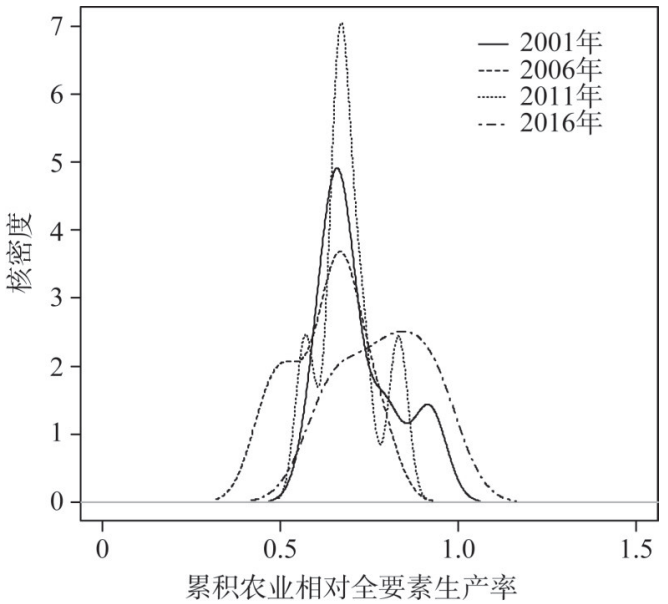

图 6 渝东南翼地区农业全要素生产率演进

Fig. 6 Agricultural total factor productivity evolution of Chongqing's southeast wing area 
（1）技术效率与技术进步滞后型，涉 及县（区）数最多，主要分布在一小时经 济圈，包括巴南区、綦江区、合川区和潼 南县等地; 另外，在渝东北翼地区的城口 县、梁平县、忠县和石柱县以及渝东南翼 地区的秀山县也有分布。该类型地区 TFP 增长缓慢是由技术效率和技术进步滞后共 同导致。对于一小时经济圈的江津区、潼 南县等来说, 耕地资源相对较为丰富, 农 业在当地经济发展中占有重要地位, 但农 业生产技术推广难、农业机械化水平低、 龙头企业带动能力低等问题依然严重。建 议未来扶持龙头企业做大做强, 培育壮大 主导产业, 拓展农业特色产业链和价值 链。对渝东北翼城口县、石柱县等地, 建

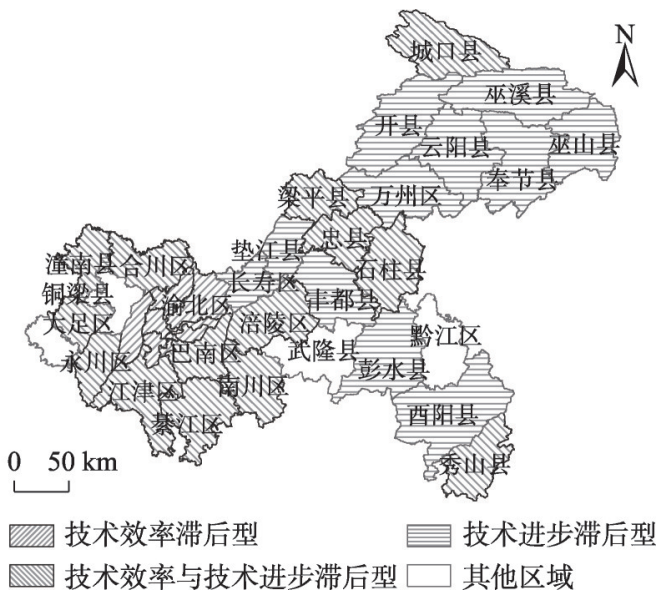

图 7 2000-2016年重庆市农业生产效率 问题类型及分布

Fig. 7 Types and distribution of agricultural production efficiency in Chongqing during 2000-2016

议立足生态资源优势，发展生态特色效益农业，推进休闲农业和乡村旅游差异化、特色 化发展。

（2）技术进步滞后引发 TFP 增长滞后型，共涉及11个县（区）。该类型在渝东北翼 地区主要以组才的方式分布在巫溪县、巫山县、开县、云阳县、奉节县和万州区等地, 在渝东南翼地区则主要分布在彭水县和酉阳县。该类型地区表现为技术进步指数低于全 市均值，技术进步滞后的负效应大于技术效率改善的正效应，导致全要素生产率增长低 于全市均值。对于渝东北翼地区来说，健全农业技术服务推广体系，提高农业科技创新 成果转化率; 加大对传统加工技术的改造力度, 提高农产品精深加工水平, 着力培育绿 色食品加工业。对于渝东南地区来说, 建议加强病虫害防治、山区农业装备、良种繁育 等现代农业技术的研发、推广和应用; 重点打造茶叶、中药材、魔芋等特色产业链, 培 育高山休闲纳凉、乡村生态民俗文化旅游等独具特色的优势产业。

（3）技术效率滞后型，涉及到 8 个县（区)，主要分布在大渡口区、江北区、沙坪坝 区、九龙坡区等都市区，同时还包括一小时经济圈的璧山县。该类型地区表现为技术效 率增长低于全市均值，但技术进步变化明显高于全市均值，技术进步的正效应大于技术 效率滞后的负效应，推动全要素生产率较快提升。该类型地区具有交通便利、经济发达 以及市场等优势，有助于现代农业技术的推广和应用，也有利于生态高效农业的发展， 但也存在农业基础设施陈旧老化等问题。建议在今后发展过程中，应充分利用都市区的 优势, 实现生产、加工、销售一体化, 提高农产品的附加值; 利用大都市对农业生产的 资本要素投人，加强农田水利等基础设施建设，加快现代农业发展。

\section{3 结论与讨论}

本文使用DEA-Malmquist 指数方法对 2000-2016年重庆市各县（区）农业全要素生产 率进行测算，在此基础上系统考察重庆市农业全要素生产率的时空演进特征，并识别出 
相关问题区域, 得出主要结论如下：（1）时间上, 重庆市农业全要素生产率指数呈现出 明显的 “U” 型波动和阶段性特征, 整体上呈增长趋势。农业 TFP 增长主要是技术进步 推动，技术效率的贡献有限。(2) 空间上，重庆市农业全要素生产率呈现出明显的空间 不平衡性。一小时经济圈的农业全要素生产率最高, 渝东南翼地区次之, 渝东北翼地区 最后, 增长率分别为 $3.3 \% 、 0.3 \%$ 和- $0.6 \%$ 。（3）2001-2016年重庆市农业全要素生产率地 区差距逐渐变大, 从 “单峰” 分布逐渐向 “多峰” 分布转变。从三大区域来看, 一小时 经济圈地区农业全要素生产率的地区差距逐渐变大，由 “一大一小” 的“双峰” 分布逐 渐向 “单峰” 分布转变。渝东北翼地区农业全要素生产率地区差距变化且呈现多极分化 趋势。渝东南翼地区农业全要素生产率地区差异逐渐减小，由“多峰” 分布向 “单峰” 分布转变。(4) 通过叠加分析识别出技术效率与技术进步滞后型、技术进步滞后型和技 术效率滞后型三类问题区域。技术效率与技术进步滞后型的县（区）数量最多, 主要分 布在一小时经济圈，技术进步滞后型主要在渝东北翼地区主要以组团的方式分布，而技 术效率滞后型的县（区）数量最少，主要分布在都市区。

根据实证研究结论，提出以下政策建议：（1）提升农业科研创新能力，同时更加注 重农业新技术、新成果的推广和应用。积极引导和鼓励工商业和私人资本投资于农业, 加大农业科研投人，大力开发适合山地丘陵地区的农业关键技术和先进适用技术。另 外，加强农业技术服务推广体系建设，解决农业科技推广最后 “一公里” 问题，通过依 靠科技进步和效率提升全面提高全要素生产率，实现农业转型发展。（2）加强对渝东北 翼和渝东南翼地区的政策扶持力度, 努力实现区域协调发展。一方面, 渝东北翼和渝东 南翼等地区自身应通过模仿学习先进适用技术和优化农业生产要素配置效率来提高农业 全要素生产率。重庆市都市区应加强对渝东南和渝东北区县科技辐射的力度, 带动整个 重庆农业经济发展。另一方面，在保证都市区农业持续稳定健康发展前提下，政府应给 予渝东南和渝东北地区足够的政策支持，完善农业基础设施，培育新型职业农民，提高 农业机械化水平，促进农业全要素生产率的提高，努力缩小与地区差距。（3）提升农业 产业化经营水平，加快推进农业现代化进程。各地区要立足当地实际，结合自身农业发 展水平和资源禀赋优势, 明确目标定位并体现出差异化的发展策略, 探索创新产业化经营 机制, 实施 “一村一品” 强村富民工程, 不断探索具有地区优势特色的产业, 促进农业转 型升级。

\section{参考文献(References):}

[1] 王冰. 中国农村社会转型模式、特征和趋势分析. 经济学家, 2007, (4): 97-102. [WANG B. Analysis of social transformation modes, characteristics and trends in rural China. Economist, 2007, (4): 97-102.]

[2] 张凤. 中国农村经济转型分析与实例研究. 农村经济, 2011, (2): 27-29. [ZHANG F. Analysis of China's rural economy transformation and case studies. Rural Economy, 2011, (2): 27-29.]

[3] 龙花楼, 邹健, 李婷婷, 等. 乡村转型发展特征评价及地域类型划分: 以“苏南一陕北”样带为例. 地理研究, 2012, 31 (3): 495-506. [LONG H L, ZOU J, LI T T, et al. Study on the characteristics and territorial types of rural transformation development: The case of "Southern Jiangsu-Northern Shaanxi" transect. Geographical Research, 2012, 31(3): 495-506.]

[4] 李裕瑞, 杨乾龙, 曹智. 长江经济带农业发展的现状特征与模式转型. 地理科学进展, 2015, 34(11): 1458-1469. [LI Y R, YANG Q L, CAO Z. Current status and pattern transformation of agricultural development in the Yangtze River Economic Belt. Progress in Geography, 2015, 34(11): 1458-1469.]

[5] 邵夏珍. “增人不增地、减人不减地”试验与农村转型: 黔省 500 农户样本. 改革, 2014, (12): 70-81. [SHAO X Z. Test 
of "Do not increase rural land as the increase in population and do not reduce rural land as the reducing in population" and rural transformation: 500 farmer samples in Guizhou province. Reform, 2014, (12): 70-81.]

[6] 刘奇. 农村社会转型与“三农”政策取向. 中国农村经济, 2007, (4): 4-11. [LIU Q. Rural social transformation and the "three agricultures" policy orientation. Chinese Rural Economy, 2007, (4): 4-11.]

[7] 赵形, 马晓冬, 周玉玉. 江苏省农村经济转型发展的区域分异. 经济地理, 2014, 34(1): 128-132. [ZHAO T, MA X D, ZHOU Y Y. The regional differentiation of rural economic transformation development in Jiangsu province. Economic Geography, 2014, 34(1): 128-132.]

[8] 赵红军. 新农村建设、农业转型与工业化城市化: 一个新农村建设作用机制的经济学分析. 南开经济研究, 2010, (6): 47-64. [ZHAO H J. New rural reconstruction, agricultural transition, industrialization and urbanization: An economic analysis of the economic mechanisms of the new rural reconstruction in Chinese economic development. Nankai Economic Studies, 2010, (6): 47-64.]

[9] 龚为纲, 黄娜群. 农业转型过程中的政府与市场: 当代中国农业转型过程的动力机制分析. 南京农业大学学报: 社会 科学版, 2016, 16(2): 73-83. [GONG W G, HUANG N Q. Market and state in the agrarian change: An analysis of dynamics of agrarian change in contemporary China. Journal of Nanjing Agriculture University: Social Sciences Edition, 2016, 16(2): 73-83.]

[10] 郑有贵. 农业转型升级对政府强依赖的原因及其对策: 兼论农业组织化实现形式的优化和转型. 农业经济问题, 2016, 37(10): 4-8. [ZHENG Y G. The reasons and countermeasures for the government's strong dependence on the transformation and upgrading of agriculture: Concurrently on the optimization and transformation of the organizational form of agriculture. Issues in Agricultural Economy, 2016, 37(10): 4-8.]

[11] 张富刚, 刘彦随, 张濛文. 我国东部沿海地区农村发展态势评价与驱动力分析. 自然资源学报, 2010, 25(2): 177-184. [ZHANG F G, LIU Y S, ZHANG Y W. Analysis of rural development state and driving force in eastern costal China. Journal of Natural Resources, 2010, 25(2): 177-184.]

[12] 翁鸣. 中国农业转型升级与现代农业发展: 新常态下农业转型升级研讨会综述. 中国农村经济, 2017, (4): 88-95. [WENG M. China's agricultural transformation upgrading and modern agricultural development: A summary of the symposium on agricultural transformation upgrading under the new normal. Chinese Rural Economy, 2017, (4): 88-95.]

[13] 罗明忠, 万俊毅. 中国农业转型发展: 经验、启示与展望: 首届农业经济理论前沿论坛综述. 经济研究, 2017, 52(6): 198-203. [LUO M Z, WANG J Y. China's agricultural transformation and development: Experience, enlightenment and prospects: A summary of the first forum on the frontiers of agricultural economic theory. Economic Research Journal, 2017, 52(6): 198-203.]

[14] 匡远配, 陆钰凤. 农地流转实现农业、农民和农村的同步转型了吗. 农业经济问题, 2016, 37(11): 4-14. [KUANG Y P, LU Y F. Does farmland transfer bring about the synchronous transformation of agriculture, farmer and rural area. Issues in Agricultural Economy, 2016, 37(11): 4-14.]

[15] 杨公齐. 农地使用权转让价格与农村社会转型. 经济社会体制比较, 2013, (2): 55-64. [YANG G Q. Agricultural land use rights transfer prices and rural social transformation. Comparative Economic \& Social Systems, 2013, (2): 55-64.]

[16] 黄海峰, 李铭. 中国农村经济转型的金融支持研究. 农村经济, 2014, (4): 73-77. [HUANG H F, LI M. Research on financial support of China's rural economy transformation. Rural Economy, 2014, (4): 73-77.]

[17] RAY C. Culture, intellectual property and territorial rural development. Sociologia Ruralis, 1998, 38(1): 3-20.

[18] 沈惊宏, 孟德友, 陆玉鹿其. 俒江城市带承接长三角产业转移的空间差异分析. 经济地理, 2012, 32(3): 43-49. [SHEN J H, MENG D Y, LU Y Q. The analysis of spatial difference of Wanjiang demonstration zone undertaking the Yangtze River Delta's industry transfer. Economic Geography, 2012, 32(3): 43-49.]

[19] HEADEY D, ALAUDDINB M, RAO D S P. Explaining agricultural productivity growth: An international perspective. Agricultural Economics, 2010, 41(1): 1-14.

[20] TRINDADE F, FULGINITI L E. Is there a slowdown in agricultural productivity growth in South America. Agricultural Economics, 2015, 46(1): 69-81.

[21] KALIRAJAN K P, OBWONA M B, ZHAO S. A decomposition of total factor productivity growth: The case of China's agricultural growth before and after reform. American Journal of Agricultural Economics, 1996, 78(2): 331-338. 
[22] WU S X, DAVID W, STEPHEN D, et al. Productivity growth and its components in Chinese agriculture after reforms. Review of Development Economics, 2001, 5(3): 375-391.

[23] MAO W N, KOO W W. Productivity growth, technological progress, and efficiency change in Chinese agriculture after rural economic reforms: A DEA approach. China Economic Review, 1997, 8(2): 157-174.

[24] 全炣振. 中国农业全要素生产率增长的实证分析: 1978-2007. 中国农村经济, 2009, (9): 36-47. [QUAN J Z. Empirical analysis of agricultural total factor productivity growth in China: From 1978 to 2007. Chinese Rural Economy, 2009, (9): 36-47.]

[25] 李谷成, 冯中朝, 范丽霞. 农户家庭经营技术效率与全要素生产率增长分解: 1999-2003 年: 基于随机前沿生产函数 与来自湖北省农户的微观证据. 数量经济技术经济研究, 2007, (8): 25-34. [LI G C, FENG Z C, FAN L X. An empirical analysis on the technical efficiencies and the decomposition of TFP of farm's household management. Quantitative Economic and Technical Economic Research, 2007, (8): 25-34.]

[26] 朱娅, 应瑞瑶. 农民的现代性与农业全要素生产率: 基于江苏省农户调查的实证分析. 华东经济管理, 2011, 25(11): 1-5. [ZHU Y, YING R Y. Modernization quality and agricultural total factor productivity: Empirical analysis based on the household survey from Jiangsu. East China Economic Management, 2011, 25(11): 1-5.]

[27] 马晓冬, 孙晓欣. 2000 年以来江苏省农业转型发展的时空演变及问题区识别: 基于全要素生产率的视角. 经济地 理, 2016, 36(7): 132-138. [MA X D, SUN X X. Space-time evolvement and problem area diagnosis of agriculture transformation development in Jiangsu province since 2000: Based on a total factor productivity perspective. Economic Geography, 2016, 36(7): 132-138.]

[28] 严先锋, 王辉, 黄靖. 绿色转型视角下地区农业发展与干预机制研究: 基于农业绿色全要素生产率的分析. 科技管 理研究, 2017, 37(21): 253-260. [YAN X F, WANG H, HUANG J. On regional agricultural development and interventional mechanism from green transformation's perspective: Based on the analysis of total factor productivity. Science and Technology Management Research, 2017, 37(21): 253-260.]

[29] 李谷成. 中国农业的绿色生产率革命: 1978-2008年. 经济学: 季刊, 2014,13(2): 537-558. [LI G C. The green productivity revolution of agriculture in Chinese from 1978 to 2008. China Economic Quarterly, 2014, 13(2): 537-558.]

[30] FÄRE R, GROSSKOPF S, NORRIS M, et al. Productivity growth, technical progress and efficiency change in industrialized countries. The American Economic Review, 1994, 87(5): 66-83.

[31] HALL R, JONES C. Levels of economic activity across countries. American Economic Review, 1997, 87(2): 173-177.

[32] 郭庆旺, 赵志耘, 贾俊雪. 中国省份经济的全要素生产率分析. 世界经济, 2005, (5): 46-53. [GUO Q W, ZHAO Z Y, JIA J X. The analysis of provincial total productivity in China. The Journal of Word Economy, 2005, (5): 46-53.]

[33] 尹朝静, 李谷成, 贺亚亚. 农业全要素生产率的地区差距及其增长分布的动态演进: 基于非参数估计方法的实证研 究. 华中农业大学学报: 社会科学版, 2016, (2): 38-46. [YIN C J, LI G C, HE Y Y. Regional disparity of agriculture total factor productivity and its growth dynamic evolution: Based on non-parametric estimation methods. Journal of Huazhong Agriculture University: Social Sciences Edition, 2016, (2): 38-46.] 


\title{
Spatiotemporal evolvement and problem region diagnosis of agricultural transformation in Chongqing city: Based on a total factor productivity perspective
}

\author{
YIN Chao-jing ${ }^{1,2}$, LI Zhao-liang ${ }^{3}$, LI Qian-nan ${ }^{4}$, ZHAO Tong-lin ${ }^{1,2}$ \\ (1. Research Centre of Rural Economics and Management, Southwest University, Chongqing 400715, China; \\ 2. College of Economics \& Management, Southwest University, Chongqing 400715, China; \\ 3. School of Law and Business, Wuhan Institute of Technology, Wuhan 430205, China; \\ 4. College of Economics \& Management, Huazhong Agricultural University, Wuhan 430070, China)
}

\begin{abstract}
Studying the law of spatiotemporal evolution of agricultural total factor productivity is of great significance to formulate the agricultural transformation and upgrading policies rationally. This paper, which is based on the calculation of agricultural total factor productivity growth from 37 counties in Chongqing over the period 2000-2016 by using DEA-Malmquist index model, investigates characteristics of spatiotemporal evolution of agricultural total factor productivity by using spatial analysis and Kernel density estimation methods and identifies the problem regions of Chongqing. The results are listed as follows: (1) From 2000 to 2016, the agricultural total factor productivity is on the rise. The agricultural total factor productivity index has a tendency of "U" type and periodic fluctuation, which shows obvious spatial imbalance. (2) The change trend of agricultural total factor productivity index is similarly consistent with that of technical progress index, which indicates that the technology progress is the main reason for total factor productivity growth. (3) From the view of the whole city, the Kernel density curve of agricultural total factor productivity keeps moving to the right, and the crest height continues to rise. The crest shape changes from "unimodal" to "multi-modal" distribution, which implies that the regional disparity of agricultural total factor productivity shows an increasing trend during the study period. (4) According to the relationship among agricultural total factor productivity growth, technical progress and technical efficiency, three types of problem regions are identified. Then policy suggestions for agricultural transformation and development are proposed for each type of problem region.
\end{abstract}

Keywords: agricultural total factor productivity; spatiotemporal evolution; Kernel density estimation; problem region 